\title{
William R. Keech: in Memoriam
}

\author{
Henry Chappell ${ }^{1} \cdot$ Michael Munger $^{2}$ (D) $\cdot$ Georg Vanberg ${ }^{2}$
}

(c) Springer Science+Business Media, LLC, part of Springer Nature 2021

William R. ("Bill”) Keech was trained as a behavioral political scientist, earning a Ph.D. from the University of Wisconsin in 1965. In the early 1980s, when he already was a wellknown mid-career scholar, he experienced a conversion toward a more interdisciplinary approach to the study of political economy and completed additional post-graduate work at the University of Michigan. He soon became a regular attendee at the annual Public Choice Society meetings and his work developed unique perspectives clearly rooted in the public choice tradition while also challenging some of its central tenets. Keech taught at the University of North Carolina-Chapel Hill from 1965 through 1996, chaired and later taught at the Department of Social and Decision Sciences at Carnegie Mellon University from 1997 to 2006, and served as Research Professor of Political Economy at Duke University from 2006 through his retirement in 2018.

In addition to his remarkable scholarly output, Bill's colleagues and friends at the Public Choice Society remember him for his tireless efforts on behalf of others, particularly junior scholars. Bill always was willing to listen and read, to think through an argument, and to provide honest feedback as well as legitimate encouragement-traits famously shared by James Buchanan. He had a remarkable ability to "step back" to see the larger picture, focusing on the broader institutional structure and the incentives that structure generates for individuals. His first publication in Public Choice, a 1977 paper on minimum wage laws and their effects, already exemplifies his ecumenical view, highlighting the political incentives for incumbent politicians to support such legislation given the logic of concentrated benefits and diffuse costs, differences in organizational frameworks across groups, and the ignorance of (some) voters.

Some of Bill's most recognized contributions were co-authored with long-time Public Choice Society member Henry "Chip" Chappell. That work includes papers in the American Political Science Review and the American Economic Review. Their 1985 Public Choice paper on "The Political Viability of Rule-Based Monetary Policy", illustrates powerfully Keech's theoretical perspective-a perspective that was, in an important sense, very

Michael Munger

munger@duke.edu

Henry Chappell

hwchappell@gmail.com

Georg Vanberg

georg.vanberg@duke.edu

1 Department of Economics, University of South Carolina, Columbia, USA

2 Department of Political Science, Duke University, Durham, USA 
much in the public choice mainstream while, at the same time, extending and qualifying it in fundamental ways. Contributing to the literature on political business cycles, Keech and Chappell adopt the standard public choice assumption of behavioral symmetry, including the assumption that the behaviors of politicians ultimately must be explained with reference to their political interests-politicians will adopt policies that are "politically viable".

But in marked contrast to standard models built on the assumption of voter ignorancewhich imply incentives for politicians to manipulate economic policy to secure voter support (resulting in political business cycles)—Keech and Chappell investigate the possibility that voters can act (or as if they do) evaluate economic policy choices by politicians in a more sophisticated manner, finding empirical support for that supposition. The conclusion they draw is that if voters are so capable, self-interested politicians may, in fact, find that sound, rule-based monetary policy is politically viable after all. It is a provocative paperusing a public choice lens to reach a conclusion that is far more optimistic than one might expect of a paper published in Public Choice.

Bill extended and deepened this work with the two editions of his celebrated book, Economic Politics: The Costs of Democracy $(1995,2012)$. The notion that "costs of democracy" might matter, which result from the incentives confronting politicians and bureaucrats to manipulate prices, the money supply, or fiscal policy, was, of course, standard fare in Public Choice circles by the 1990s. But it was still a radical claim in political science. Keech's ability to communicate public choice arguments and insights to a mainstream political science audiences established important connections between the two areas of study, which surprisingly had been treated separately in the academic literature.

Bill's final paper in Public Choice, a 2015 article on government failure written with Michael Munger, similarly highlights his creative insights in pushing forward the public choice perspective. Keech and Munger develop a novel conceptual framework that systematically extends the idea of government failure. Introducing a key distinction between substantive failure (failing to accomplish tasks properly within its scope, such as the provision of public order) and procedural failure (reliance on inadequate collective choice procedures that allow for arbitrary or manipulated decisions), they also develop a theoretically grounded standard for evaluating government failure. Finally, the paper integrates the insights of behavioral economics, demonstrating that cognitive and psychological limits to full rationality not only suggest potential "market failures", but pose similarly significant challenges to government action.

Over the years, Bill Keech attended a dozen or more PCS meetings., He always "stood out" - not just because of his unusual height (he was 6'8" tall), but even more so for his infectious enthusiasm for discussion, debate, and intellectual camaraderie.

Publisher's Note Springer Nature remains neutral with regard to jurisdictional claims in published maps and institutional affiliations. 